\title{
Interdisciplinarity of Information Science Research: Introduction
}

\author{
Barbara Sosińska-Kalata \\ ORCID 0000-0002-4511-4701 \\ Department of Information Studies, \\ Faculty of Journalism, Information and Book Studies \\ Warsaw, Poland
}

\begin{abstract}
Purpose/Thesis: The article aims to present and discuss some introductory reflections on the nature of interdisciplinarity of research conducted in the field of information science and its effect on the reorganization of the institutional setting of the discipline.

Approach/Methods: This is a conceptual review article based on theoretical considerations and critical analysis of the concept of interdisciplinarity and the features of interdisciplinary approaches employed in information science research and its effect on the position of information science in university structure.

Results and Conclusions: The concept of interdisciplinarity is discussed with reference to two aspects of the development of science: specialization and integration. The article presents selected typologies of interdisciplinarity and discusses the changes in the perception of the concept of discipline. Interdisciplinarity has been discussed as an inherent feature of information science. The types of interdisciplinarity that best correspond to the specificity of the interdisciplinary approach used in information science research has been indicated. Referring to previous studies, the article sketches the most characteristic interdisciplinary connections of information science. In general, the review shows that apart from the permanent relationship with social sciences, in particular with library science and computer science, the relationships between information science and other disciplines are variable and quite loose. Stronger relationships are most often generated through practical activity in related disciplines, in which specialized information services are the most developed and widely used. Originality/Value: The view that information science is by its very nature an interdisciplinary field of research is common among information researchers and information professionals. Much research has been done on the interdisciplinary connections of the discipline, however, by the best author's knowledge, few of them analyzed the specificity of interdisciplinarity of this field of research. This article attempts to initiate an in-depth discussion on this issue.
\end{abstract}

\section{Keywords}

Crossdisciplinarity. Information science. Institutional structures. Interdisciplinarity. Multidisciplinarity. Transsdisciplinarity. Typology.

Received: 21 September 2020. Reviewed: 24 September 2020. Accepted: 30 September 2020.

\section{Introduction}

The aim of this article is to present and discuss some introductory reflections on the nature of interdisciplinarity of information science research and its effects on the reorganization of the institutional setting of the discipline. The view that information science 
is an interdisciplinary field of research is common among information researchers and much research has focused on identifying the discipline's interdisciplinary connections. However, to the author's best knowledge, few of them analyzed the specific features of interdisciplinarity of this field of research. This article attempts to initiate an in-depth discussion on this issue. It is meant as an introduction to in-depth analyzes, allowing a better understanding of the specifics of interdisciplinary relationships of information science and their importance for the development of its research.

\section{The concept of interdisciplinarity}

In recent years, interdisciplinarity has become a key term in discussions of changes in science, organization of research, and universities. Declarations of the development of interdisciplinary research and the establishment of interdisciplinary research groups are increasingly common in the operating strategies of governments, organizations and scientific associations, universities, research institutions and their internal units. In their missions statements, research journals claim to have a particular interest in interdisciplinary research. Such statements usually relate interdisciplinarity to innovation. The interdisciplinary approach is promoted as a modern model of research practice, which, by crossing the boundaries of traditional disciplines and the paradigms they adopted, provides a new, broader perspective on the studied phenomena and finds comprehensive solutions to complex problems, with which research adhering to traditional boundaries between the disciplines cannot cope (see e.g. Wernli \& Darberllay, 2016). Interdisciplinarity is therefore seen as a remedy for the limitations of research conducted according to the models defined by the traditional disciplines.

However, interdisciplinary research is by no means a modern invention. The interdisciplinary approach to scientific research has a long history, even if it is only recently that the concept of interdisciplinarity has become popular in meta-scientific discourse. According to Raymond C. Miller, the concept of interdisciplinarity began to be discussed in the social sciences in the early 1970s, along with intensive promotion of the implementation of an interdisciplinary approach in research and in university education. Interdisciplinarity: Problems of Teaching and Research in Universities, a report published by the Organization for Economic Co-operation and Development (OECD) in 1972 (Miller, 2010, 2) was the first comprehensive publication on the topic. Piotr Nowak and Piotr Wierzchon (2020), basing on an analysis of digitized scientific publications collected in the resources of the Polish Digital Libraries Federation (Federacja Bibliotek Cyfrowych - FBC), prove that the term "interdisciplinarity" first appeared in the Polish language in 1966 on the pages of the journal Przeglad Biblioteczny. Thus, scholars have been discussing the importance of interdisciplinarity in scientific research for about 50 or 60 years, but it must be remembered that from the earliest times the development of science has been driven by two parallel and complementary phenomena: the phenomenon of differentiation and specialization, and the phenomenon of integration and unification. The former assumes both a gradual narrowing of the area of research and changing the way in which researchers work, introducing new theories and research methods. Of course, the differentiation and specialization of science deepen the knowledge of the world, improve the research methods and 
increase the effectiveness of research by the division of labor. However, they also create an ever deeper division of science into disciplines of an ever-narrowing scope, and, at the same time, increase the distance between researchers and the isolation and particularism of research in individual scientific disciplines. The simultaneous integration and unification of science proceed beyond the previously established divisions, forming connections between disciplines, strengthening the unity of scientific cognition and filling the gaps in those areas of research, where exploration and explanation based on the methods and theories of individual disciplines have proved insufficient. The tension between the unity and the multiplicity of sciences is one of the most important forces of progress in science (cf. Kamiński, 1998, 249).

An interdisciplinary approach is necessary for both in-depth and complete understanding of the world in which humanity functions. On the one hand, the disciplinary divisions have led to establishing a huge number of detailed disciplines allowing a more and more detailed understanding of various areas of reality; on the other hand, they have revealed the connections between previously separated disciplines. The disclosure of such connections was a result of the discovery of common aspects of various phenomena (e.g. heat and motion, light and electromagnetism), the widespread use of mathematical methods in an increasing number of sciences (both natural and social sciences), the integration of research in physics, chemistry and technology, followed by the integration of research in biology and medicine, the interest in universalist mathematical structures and the development of the most general theories, allowing the scholars to explain phenomena studied by various fields of science (e.g. general systems theory, cybernetic theories, ecological theories), and, recently, the digitization of scientific research big data analysis, concerning various areas of the world and human life. Although the specialization of science continues at a rapid pace, since the mid-twentieth century, the accuracy of scientific insight based on research conducted in fields with an ever-narrowing scope has been increasingly questioned, while the model of interdisciplinary research has become more and more popular as the effective solution for this problem. Since then, the discussion of interdisciplinarity has developed in research, which led some authors to identify this stage of the development of science as the era of interdisciplinarity (cf. Dudzikowa et al., 2012, 9).

The concept of "interdisciplinarity" is most often defined as a result of the involvement of more than one discipline in certain activities. For example, according to the Cambridge Advanced Learner's Dictionary E Thesaurus, the noun "interdisciplinarity" means

the fact of involving two or more different subjects or areas of knowledge:

The key characteristic of this work is its interdisciplinarity.

Interdisciplinarity and collaboration across faculties and between departments are strong features of research activity within the university (Interdisciplinarity, n.d.).

According to the Stownik Jezzkka Polskiego PWN (PWN Dictionary of the Polish Language), the adjective "interdisciplinary" (Pl. interdyscyplinarny) means:

concerning two or more scientific disciplines;

building on the achievements of several sciences;

composed of scientists representing various branches of knowledge (Interdisciplinarny, n.d.) ${ }^{1}$.

${ }^{1}$ In the original version: (1) dotyczący dwu lub więcej dyscyplin naukowych; (2) korzystający z dorobku kilku nauk; (3) złożony z naukowców reprezentujących różne gałęzie wiedzy. 
In scholarship, however, the term "interdisciplinarity" does not have a uniform definition. Julie Thompson Klein, in the conclusion of her extensive review of the interdisciplinary literature in the book Interdisciplinarity: History, Theory, and Practice, notices that:

Interdisciplinarity has been variously defined in this century: as a methodology, a concept, a process, a way of thinking, a philosophy, and a reflexive ideology. It has been linked with attempts to expose the dangers of fragmentation, to reestablish old connections, to explore emerging relationships, and to create new subjects adequate to handle our practical and conceptual needs. Cutting across all these theories is one recurring idea. Interdisciplinarity is a means of solving problems and answering questions that cannot be satisfactorily addressed using single methods or approaches. Whether the context is a short-range instrumentality or a long-range reconceptualization of epistemology, the concept represents an important attempt to define and establish common ground (Klein, 1991, 196).

\section{Types of interdisciplinarity}

Interdisciplinary research is conducted in almost all fields of modern science, and that may sometimes create misunderstandings. Rick Szostak noticed that, until a few decades ago, the main intellectual challenge to quality interdisciplinary research was to falsify the view that this type of research is inherently superficial, which was popular among researchers of traditional academic disciplines and justified by the claim that a solid mastery of one discipline requires many years, and therefore an equally solid mastery of a few is not possible. Currently, the challenge is to disprove the increasingly popular belief that any research can be interdisciplinary (Szostak, 2013). It must therefore be emphasized that interdisciplinary research requires

the integration of insights from multiple disciplines in order to better understand some complex topic that is that is addressed from different perspectives by different disciplines. (...) Quality interdisciplinary work requires a serious engagement with each discipline one draws upon: This is far from impossible, but also far from being easy (Szostak, 2013, 44-45).

The essence of interdisciplinarity in science is not in the combination of theories and methods from various disciplines, but in the synergy emergent from that combination, resulting in a comprehensive understanding of complex problems and proposing coherent solutions to them (Dudzikowa et al., 2012, 9).

There are many types of interdisciplinary connections characterized by a different degree of the integration of co-operating disciplines. There are also many typologies of interdisciplinary connections. For example, Stanisław Kamiński, a methodologist and philosopher, distinguished four types of interdisciplinary research areas:

(1) border disciplines - emerging at the interface between several disciplines, e.g. physical chemistry, biochemistry, biophysics, geophysics, astrophysics, psycholinguistics, sociolinguistics, etc.;

(2) universalizing disciplines - e.g. cybernetics, general systems theory;

(3) comprehensive disciplines - e.g. science of science, space sciences;

(4) sets of disciplines related only to a common topic, e.g. semiology, pedagogy (Kamiński, 1998, 249).

Shiyali Rammamrita Ranganathan, mathematician and librarian well known in information science as the creator of faceted classification and facet analysis, distinguished five types of interdisciplinary connections by analyzing the structure of research topics: 
(1) agglomeration, i.e. compiling components from various disciplines into a larger set, e.g. life sciences, social sciences, humanities;

(2) loose-assemblage, consisting in a relatively small interaction of two disciplines in the form of orientation, the use of a research tool, comparison or influence, e.g. computerization of libraries, comparative studies of Judaism and Christianity, the use of rhetorical methods to study scientific texts in the science of science;

(3) fusion, i.e. merging the research areas of two disciplines into an internally coherent new discipline, e.g. biochemistry, geopolitics, sociolinguistics;

(4) distillation, i.e. extracting certain related concepts from several disciplines or sub-disciplines and organizing a new discipline around them, e.g. methodology of sciences, forestry, management science;

(5) clustering or subject bundles, i.e. focusing the interest of various research disciplines on a certain multifaceted analyzed object or problem, most often taking the form of the so-called area or mission oriented studies, e.g. cultural studies, women studies, cognitive science (Ranganathan, 2006).

Mohinder P. Satija added one more type of interdisciplinary connections to Ranganathan's list:

(6) annexation mode, which consists in isolating from traditional disciplines issues related to a selected object or activity and loosely combining them in the structure of a new research area, e.g. physical education (sports science) (Satija et al., 2014).

Ingetraut Dahlberg, philosopher and historian of science, and researcher of the organization of knowledge, distinguished five types of integration of the sciences:

(1) interdisciplinarity - characterizing research in which the issue of a certain discipline is analyzed from the point of view of other disciplines, e.g. educational psychology, sociology of education, educational policy, educational legislation, educational economics. philosophy of education;

(2) transdisciplinarity - which arises as a result of the penetration of the theory and / or research methods of one discipline into many other disciplines, e.g. energy politics, agricultural politics, environmental politics, financial politics, culture politics, etc.; Another example of transdisciplinarity is the formation of new disciplines that use statistical methods to study various areas of the world, e.g. scientometrics, bibliometrics, psychometrics, econometrics, etc.;

(3) multidisciplinarity - characterizing the areas of multifaceted analysis of a selected research object, the aim of which is to use the contribution of various disciplines to solve a certain problem, e.g. the study of critical phenomena such as earthquakes, floods, AIDS, radicalism, fundamentalism; the space science, commodity science, transportation, etc.;

(4) pluradysciplinarity - manifested by conducting research on the same complex phenomenon, usually weakly interconnected within various disciplines, e.g. security: security of computers, the security of information, the security of buildings, the security of space ships, the security of power plants;

(5) syndisciplinarity - which is the case of the strongest interdisciplinary links in research, when a number of disciplines work together to obtain a complete synthesis of research results, e.g. nanotechnology (Dahlberg, 1994).

Finally, the recent typology of interdisciplinarity presented by Raymond C. Miller (2020) should be mentioned as well. He distinguished three types of interdisciplinary research approach: 
(1) multidisciplinary approaches - that involve the process of juxtaposing parts of some conventional disciplines in the effort to get a broader understanding of some common problem; integration of the participating disciplines is weak and their identities and research practices are not threatened; team-taught courses or ad hoc research teams are examples of this approach;

(2) crossdisciplinary approaches - involve real interaction across conventional disciplines, but the extent of integration of their concepts and / or methods may vary significantly; the six subcategories of crossdisciplinarity are distinguished: (a) topics of social interest focused on some social problems, e.g. area studies, gerontology, labor studies, urban studies; (b) professional preparation focused on relevant knowledge for professional activities in a specific area, e.g. business management, diplomatic studies, education, health studies, policy studies; (c) shared analytical methods focused on research methods used across different disciplines, such as statistics, computer modeling, game theory, information theory, etc.; (d) shared concepts that appear in many disciplines, like energy, value, role, evolution, development, cycles, rational choice, etc.; (e) hybrids combining parts of two existing, related disciplines to create interstitial new crossdisciplines that attempt to bridge perceived gaps between disciplines, e.g. social psychology, political economy, bio-geography; (f) shared life experiences focused on the premise that certain social groups share an experience of oppression that gives them shared identity, shared rejection of mainstream knowledge and shared political agenda to replace the unjust social conditions with an egalitarian society, e.g. women studies, ethnic studies, post-colonial studies, refuge studies;

(3) transdisciplinary approaches "involve articulated conceptual frameworks that seek to transcend the more limited worldviews of specialized conventional disciplines" (Miller, 2020, 11); transdisciplinary approaches provide worldviews alternative or supplementary to the conventional disciplines, e.g. general systems theory, cultural studies, gender theory, symbolic interactionism.

The development of interdisciplinarity is often considered to be a phenomenon opposite to the specialization of science, but it is more appropriate to perceive them as complementary. The division of science into classical academic disciplines is a traditional method of organizing scientific knowledge, research institutions and university education, while interdisciplinarity is a method of reorganizing them by designating new configurations and connections (cf. Moran, 2010). It is also worth noting that areas of interdisciplinary research, similarly to specialized fields distinguished in the process of deepening the division between conventional disciplines, strive to consolidate their legitimacy through various forms of institutionalization, from organizing national and international conferences, starting their own journals and scientific societies, to establishing separate units in the structures of universities and other research institutions. Although, according to the classical definition of a scientific discipline, interdisciplinary research areas have not that status, many such areas have long functioned as independent disciplines. These include, for example, pedagogy, management science, as well as information science. The areas of interdisciplinary research are sometimes called "new types of disciplines", neodisciplines, interdisciplines, crossdisciplines, or transdisciplines (Miller, 2020). A few years ago, Carel Stephanus de Beer (2015) published a monograph devoted to the presentation of information science as an interscience. 


\section{Interdisciplinarity as an inherent feature of information science}

Many scholars of information science agree that information science is by its very nature an interdisciplinary field of research. It was formed as an interdisciplinary project, and its pioneers were researchers of various disciplines, both of pure sciences and engineering, as well as social sciences and humanities, conducting both basic and applied research. Their common aim was to ensure efficient access to relevant information, meeting the needs of users seeking it in growing resources of recorded knowledge. Specialists from various fields contributed both ideas derived from their mother disciplines, theories, concepts and research methods useful for information research, as well as experiences related to the information needs specific to these disciplines, methods of satisfying them and ways to overcome various barriers to the efficient operation of information processes.

In 1968, Harold Borko presented one of the first accounts of information science as an interdisciplinary area with a broad research agenda. According to him, information science emerged from studies exploring the properties and behavior of information, the forces governing its flow, and the means of processing it to optimize collection, storage, retrieval and use:

It is an interdisciplinary science derived from and related to such fields as mathematics, logic, linguistics, psychology, computer technology, operational research, the graphic arts, communications, library science, management, and other similar fields. It has both a pure science component, which inquiries into the subject without regard to its application, and an applied science component, which develops services and products (Borko, 1968, 3).

Borko considered librarianship and documentation to be applied aspects of information science.

Thirty years later, Tefko Saracevic (1999) referred to Borko's concept in one of the most frequently cited characterizations of information science, emphasizing interdisciplinarity as its defining feature, alongside its focus on solving the problems of information explosion, and on ensuring an effective transfer of recorded knowledge with the use computer technology. Saracevic argued that interdisciplinary relationships of information science are constantly changing, and that the process of shaping these connections is far from over. He highlighted two aspects of information science's relationships with other disciplines. Firstly, research problems of information science which relate to effective transfer of knowledge in modern information society are inherently complex and multifaceted, and thus cannot be solved with the use of approaches and concepts developed in one discipline only. Therefore, an interdisciplinary approach is a prerequisite of effective research in information science. Secondly, the main source of interdisciplinarity of information science is the diversity of backgrounds of researchers working in this field. They are very diverse, but the actual contribution of the disciplines to the development of information science is also very varied. So far library science and computer science have had the greatest impact on the development of the research agenda for information science. Library science and information science share a social role and an interest in the effective use of accumulated knowledge. Computer science provides information science with methods and technological tools for formulating practical solutions to its main problems. It should also be noted that Saracevic emphasizes that information science is a separate discipline, however strongly associated with library science and computer science. 
Interdisciplinary connections of information science are constantly evolving as a consequence of changes in its so called intellectual structure. However, two dominant orientations have been present from the outset:

\begin{abstract}
toward the human and social need for and use of information pertaining to knowledge records, on the one hand, and toward specific information techniques, systems, and technologies (covered under the name of information retrieval) to satisfy that need and provide for effective organization and retrieval of information, on the other hand. From the outset, information science had these two orientations: one that deals with information need, or more broadly human information behavior, and the other that deals with information retrieval techniques and systems (Saracevic, 2010, 2570).
\end{abstract}

These two orientations continue to develop now, but become increasingly independent from one another, which is confirmed e.g. by co-citation studies (White \& McCaine, 1998). The growing gap between information science focused on social issues and information science focused on computer technology is reflected in the structures of many institutions of higher education. It has been evident in some classification schemas organizing research. For example, OECD Field of Science and Technology Classification includes information science in section 1 Natural sciences, in sub-section 1.2 Computer and information sciences, and in section 5 Social sciences, in sub-section 5.8 Media and communication - Information science (social aspects) (OECD, 2007). This scheme, with minor changes, was the basis of the new division of scientific fields and disciplines that was a part of the recent reorganization of the structure of universities in Poland. As a result, at most universities, information science focused on social aspects was incorporated into faculties or departments of social communication and media sciences, and in several cases, faculties or departments of cultural sciences. The technological aspects of information science, on the other hand, were merged with the engineering sciences (information and communication technology) or within the pure and natural sciences (the computer and information sciences). Thus, the distance between the two orientations in information science has been enlarged even further in a consequence of this arbitrary decision.

\title{
5. The interdisciplinarity of information science research
}

In each science, its interdisciplinary connections, their distribution, intensity, orientation, and models of cooperation between researchers of various specialties are shaped by the nature of the problems studied and the solutions sought. The degree of synergy of integrated theories and research methods in various sciences also varies, as do the types of interdisciplinarity emergent in such relationships. The relatively large number of disciplines involved in information science research and the variability of these correlations over time suggest that the interdisciplinary relationships of information science are rather loose. Following the typology of interdisciplinarity discussed in section three, information science can be classified as a comprehensive discipline, or a set of disciplines related only to a common topic (in Kamiński's terms), clustering or subject bundles (Ranganathan's), multidisciplinarity (Dahlberg's), and crossdisciplinary approach of the types "a - topics of social interest" and "b - professional preparation" (Miller's). Like Dahlberg, George Adam Holland recognized information science as a field of multidisciplinary research, noting that there is no explicit intent of strategic integration with collaborated disciplines 
(Holland, 2008, 14). The fact that the unequivocal identification of interdisciplinary connections specific to information science research as one of the types of interdisciplinarity distinguished in theoretical studies is not possible proves that these relationships are not only loose and variable, but also that they function on various levels (methodological, theoretical, educational, and practical).

Assessing the degree of interdisciplinarity in information science is not easy, as the literature which would be the material for such empirical analysis is usually categorized as belonging to the broader Library and Information Science (LIS) class. Firstly, it does not allow for tracing the relationship between information science and library science, and secondly, it provides information on the distribution of connections with other disciplines for information science and library science taken together. An example of such "aggregated" analysis is the bibliometric study of Vincent Larivière, Cassidy R. Sugimoto and Blaise Cronin, carried out on a large sample of data extracted from 96000 articles published over the course of 110 years (1900-2010) in 160 scientific journals currently included in the LIS category (Larivière et al., 2012). The research showed that since the 1960s, the references to literature of other disciplines in LIS papers had been systematically growing; in 2010 only approximately $36 \%$ of references made to an item in any given LIS paper referred to a LIS source. Most citations in LIS literature came from the literature on management (from $2 \%$ in 1960 to $18 \%$ in 2010) and on computer science (from 4\% in 1960 to slightly above $8 \%$ in 2010). In the case of computer science, the citation level has been consistent since the mid-1990s: it has remained at the level of approximately $8 \%$. A high level of citations was also recorded for the literature of medical sciences (6\% in 2000 with a downward trend to $4 \%$ in 2010) and pedagogical sciences (most often cited in the $1940 \mathrm{~s}-$ up to $12 \%$ of citations; since the 1970s the citation intensity remains at the level of 1-2\%). Larivière, Sugimoto, and Cronin also found a clear upward trend in references to LIS literature in research of other disciplines: from the mid-1990s to 2010, there was an increase in such citations from $20 \%$ to $60 \%$, most of them from management sciences (10\% in 2010) and computer science ( $8 \%$ in 2010). The citation analysis showed LIS research connections at the level of at least 700 references (publications citing LIS papers and cited by LIS papers) for 31 disciplines in the period 1991-2010 (Larivière et al., 2012, Fig. 11). This study also confirmed that the number of LIS researchers' publications in journals of other disciplines had increased: from $20 \%$ in the 1960 s to $60 \%$ in 2010 . An analysis of the distribution of LIS's interdisciplinary relationships compared to the distribution of such relationships in other humanities and social sciences (political science, archeology, sociology, philosophy and literary studies) showed that LIS was one of the most interdisciplinary fields of inquiry.

Taiwanese researchers Yu-Wei Chang and Mu-Hsuan Huang (2012) obtained similar results in their analysis of a much smaller sample of approx. 1500 articles published over a period of 30 years (1978-2007) in the ten journals with the highest Impact Factor. An equal number of journals was selected from both sub-categories of the LIS category: five for library science and five for information science. Because four of information science journals fell into both the LIS and CIS (Computer and Information Science) categories, the authors have arbitrarily eliminated from the sample the articles they saw as belonging to computer science. It should be noted that such decision might have affected the sample's capacity to reflect LIS's interdisciplinarity. On the other hand, determining the scope and nature of LIS's interdisciplinary relationships was not the main aim of Chang's and Huang's research, 
which primarily focused on testing three methods employed in bibliometric analyzes of interdisciplinarity in science: direct citation, bibliographic coupling and co-authorship analysis. According to the data of Chang and Huang, the results obtained with the use all three methods showed a similar degree of influence of other disciplines on LIS research (from $50 \%$ for direct citation and co-authorship to $34 \%$ for bibliographic references). According to the study, the disciplines in the general science category (covering the science of science) had the strongest connections with LIS - from 7.1 to $13.2 \%$; business / management - from 1.8 to $4.4 \%$; computer science - from 2.7 to $7.6 \%$ and pedagogical sciences - from 0.9 to $3.4 \%$. These studies also found a clear upward trend in citations of literature from other disciplines, but a decrease in references to LIS found in the research of other disciplines.

The "aggregated" approach was employed also in Yu-Wei Chang's (2018) study of external contributors to LIS knowledge who, although unaffiliated with LIS-related institutions, published their research results in LIS journals; the differences between contributors to library science and contributors to information science were also considered. Analyzing the sample of 11641 articles published in 2005-2014 in 39 strongly LIS-oriented journals indexed in the Web of Science database, the study demonstrated that more than $46 \%$ of the LIS articles were written by at least one non-LIS author, with the authors' backgrounds ranging across 29 disciplines. In the period studied, an increasing trend of interdisciplinarity was apparent both in information science and in library science. Almost 70\% of non-LIS authors were affiliated with institutions related to computes science (47.4\%) or business and economics (20.6\%). The number of non-LIS authors publishing in the information science journals was three times the number of non-LIS authors publishing in library science journals. Authors with computer science background were the most frequent contributors to information science journals; authors with medical background were identified as the non-LIS authors most frequently (31.4\%) publishing in the library science journals.

The results of the bibliometric analyzes discussed above clearly show the high interdisciplinarity of LIS research, situating LIS, information science and library science taken together, among the most interdisciplinary research areas in contemporary humanities and social sciences. Additionally, Chang's study showed that information science is characterized by a much higher degree of interdisciplinarity than library science.

Finally, we may recall the interesting results of the study by Zbigniew Osiński (2019), analyzing the connections between LIS, media studies and cognition and social communication sciences to verify the legitimacy of combining them into a single overarching discipline in the new division of the fields and disciplines of science recently introduced to the organization of research in Poland. Osiński applied a triangulation of qualitative and quantitative methods: an analysis of the content of review articles concerned with the research issues of these disciplines published in 2010-2018 in Polish journals considered to be the most important sources of new scholarship within the studied disciplines; an analysis of the thematic scope of the journals presented on their websites; a citation analysis of 1432 articles published in these journals in the same period, in search of references to journals representing other subdisciplines included in the newly established overarching discipline; and an analysis of the overlap of sets of keywords used in metadata of the articles. The results of the analysis of review articles showed that research fields of LIS, media studies and the cognition and social communication sciences are aligned and complementary. This observation was confirmed by the analysis of the thematic scope of the studied journals. Quantitative research revealed 
many methodological problems, e.g. related to the domination of citations from foreign literature. However, overall, the results of the citations analysis did not suggest that there was an interdisciplinary relationship between LIS, media studies, and the cognition and social communication sciences. The references to articles published in the studied Polish journals associated with other disciplines were incidental. The results of the keyword analysis also showed weak relationships between the research issues of LIS and the other two disciplines. While Osiński's research did not confirm the officially established relationships between LIS, media studies, and cognition and social communication sciences, it should be noted, however, these studies referred to actual research practices in the Polish scientific community in the analyzed period. It is an open question whether the administrative changes of the organization of research will actually result in a closer cooperation between the interconnected disciplines. It is also worth noting that, for example, according to the results of Chang's (2018) study conducted on the sample of international journals, out of non-LIS authors publishing in information science journals, only $2.3 \%$ authors were affiliated with media studies (or more generally: communication sciences).

Over the past two decades, the place of information science in the organizational structure of university education has changed in many countries, and the changes provoked many discussions regarding the impact of interdisciplinarity on the development of information science and its relationships with other sciences. Two distinct positions emerged in these discussions (Madsen, 2016), illustrating what is sometimes referred to as "the problematic situation of interdisciplinarity" (cf. Dudzikowa, 2012). Researchers leaning towards the first position focus on the problem of fragmentation of contemporary information science, its eclectic nature, and increasingly fluid and permeable boundaries, considered to be inevitable consequences of researching objects, processes, and phenomena studied also in other disciplines. This is perceived as a threat to the discipline's identity (e.g. Bates, 1999; Meadows, 2008). Researchers holding the second position see the development of multidisciplinary information research as an opportunity to solve the problems of information science, and thus - as a chance to further its development and to increase its prestige. This has been shown to be possible by the evolution of the so-called i-schools (Nolin \& Åstrøm, 2010). However, it should be remembered that $\mathrm{i}$-schools have not developed according to a uniform pattern. They take different forms in different countries and at different institutions, implement various interdisciplinary approaches and integrate different configurations of research and professional education on information phenomena and information services. In some cases, they focus more on the relationships with computer science and information technology, in others on those with social disciplines and user studies, and in others - on the traditional links with library science. There is also a visible trend of transforming former faculties or departments of library and information science, or information and library science, into faculties or departments of information science or information studies.

\section{Final remarks}

The complex and multifaceted nature of information science requires the use of the achievements of various disciplines, their methods and theories. At the same time, it seems that the interdisciplinary connections of information science are rather loose: they arise ad 
hoc in search for solutions to various specific research problems. The configuration and intensity of these connections change depending on the focus of the researchers' attention.

The most sustained interdisciplinary relationships of information science are that with computer science, despite the growing distance between research focused on social issues and research focused on technological issues - and with library science, or, more broadly, with the disciplines concerned with the collection and sharing of knowledge recorded in various forms.

The interdisciplinary approach related to professional preparation, which is specific to information science, results in a large number of interdisciplinary connections, generated by practical aspects of the use of information services and the development of information products for particular fields and disciplines. Such connections are usually of a loose nature, as they primarily involve identifying the needs of specialists in a given field to be fulfilled by information services and monitoring their utility in practice; they do not inspire a more significant involvement of this field in information research. Sometimes, however, the connection between information science and another discipline is based on the significant use of information products and of the methods of providing information services developed in information science in the other discipline's own research and practice, e.g. systematic reviews of research literature and their use in evidence-based medicine. It seems that the situation of management sciences is similar, although there, the use of research methods derived from management sciences in the management of information processes and information resources is important as well. On the other hand, the similarity of the research issues of information science and media studies, and the sciences of cognition and social communication, already indicated by theorists, has not confirmed in the analyzes of mutual citations of researchers working in these disciplines.

The research on the interdisciplinarity of information science conducted so far has most often focused on identifying disciplines with which information science enters into interdisciplinary connections. Little attention was paid to the nature of these links. Certainly, such a reflection would allow a better understanding of the phenomenon of interdisciplinarity in information science, which in turn could contribute to a more effective organization of information research and education in the field of information science at universities.

\section{References}

Bates, M. (1999). The Invisible Substrate of Information Science. Journal of the American Society for Information Science, 50(12), 1043-1050. https://doi.org/10.1002/(SICI)1097-4571

Beer, C. S. de (2015). Information Science as an Interscience: Rethinking Sccience, Method and Practice. Kidlington: Chandos.

Borko, H. (1968). Information Science: What Is It? American Documentation, 19(1), 3-5. https:// doi.org/10.1002/asi.5090190103

Chang, Y.-W. (2018). Examining Interdisciplinarity of Library and Information Science (LIS) Based on LIS Articles Contributed by Non-LIS Authors. Scientometrics, 116, 1589-1613. https//doi. org/10.1007/s11192-018-2822-7

Chang, Y.-W., Huang, M.-H. (2012). A Study of the Evolution of Interdisciplinarity in Library and Information Science: Using Three Bibliometric Methods. Journal of the American Society for Information Science and Technology, 63(1), 22-33. https://doi.org/10.1002/asi.21649 
Dahlberg, I. (1994). Domain Interaction: Theory and Practice. In: H. Albrechtsen \& S. Oernager (eds.). Knowledge Organization and Quality Management. Proceedings of the Third International ISKO Conference 20-24 June, 1994, Copenhagen, Denmark (60-71). Frankfurt/Main: Index Verlag. Dudzikowa, M. (2012). Sytuacja problematyczna interdyscyplinarności w naukach społecznych i humanistycznych (z kryzysem w tle). In: A. Chmielewski, M. Dudzikowa \& A. Grobler (eds.). Interdyscyplinarnie o interdyscyplinarności. Między idea a praktyka (10-37). Kraków: Impuls.

Dudzikowa, M., Chmielewski, A., Grobler, A (2012). Przedmowa. W: A. Chmielewski, M. Dudzikowa \& A. Grobler (eds.). Interdyscyplinarnie o interdyscyplinarności. Między ideq a praktyka (9-11). Kraków: Impuls.

Holland, G.A. (2008). Information Science: An Interdisciplinary Effort? Journal of Documentation, 64(1), 7-23. https://doi.org/10.1108/00220410810844132

Interdisciplinarity (n.d.). Cambridge Advanced Learner's Dictionary \& Thesaurus [online], [20.08.2020], https://dictionary.cambridge.org/dictionary/english/interdisciplinarity

Interdisciplinarny (n.d.). Stownik Języka Polskiego PWN [online], [20.08.2020], https://sjp.pwn.pl/ sjp/interdyscyplinarny;2466577.html

Kamiński, S. (1998). Nauka i metoda. Pojęcie nauki i klasyfikacja nauk. Ed. by A. Bronk. Lublin: Towarzystwo Naukowe KUL.

Klein, J.T. (1991). Interdisciplinarity: History, Theory, and Practice. Detroit: Wayne State University Press.

Larivière, V., Sugimoto, C., Cronin, B. (2012). A Bibliometric Chronicling of Library and Information Science's First Houndred Years. Journal of the American Society for Information Science and Technology, 63(5), 997-1016. https://doi.org/10.1002/asi.22645

Madsen, D. (2016). Liberating Interdisciplinarity from Myth: An Exploration of the Discursive Construction of Identities in Information Studies. Journal of the American Society for Information Science, 67(11), 2697-2709. https://doi.org/10.1002/asi.23622

Meadows, J. (2008). Fifty Years of UK Research in Information Science. Journal of Information Science, 34(4), 403-414. https://doi.org/10.1177/0165551508089718

Miller, R.C. (2020). Interdisciplinarity: Its Meaning and Consequences [online]. Oxford Research Encyclopedia, International Studies [30.09.2020], https://doi.org/10.1093/acrefore/9780190846626.013.92

Moran, J. (2010). Interdisciplinarity. Second ed. London, New York: Routledge.

Nolin, J., Åstrøm, F. (2010). Turning Weakness into Strength: Strategies for Future LIS. Journal of Documentation, 66(1), 7-27. https://doi.org/10.1108/00220411011016344

Nowak, P., Wierzchoń, P. (2020). Digital Libraries and the Breakthrough in Linguistic Chronologization. The Applications of Digitization in Linguistics. Zagadnienia Informacji Naukowej, 58(1A). [in print].

OECD (2007). Revised Field of Science and Technology (FOS) Classification in the Frascati Manual [online]. OECD, Committee for Scientific and Technological Policy, [5.08.2020], https://www. oecd.org/science/inno/38235147.pdf

Osiński, Z. (2019). Analysis of the Thematic Overlap Between Library and Information Science and Other Subdisciplines of the Social Communication and Media Sciences in Poland. Zagadnienia Informacji Naukowe, 57(2A), 28-44. https://doi.org/10.36702/zin.468

Ranganathan, S.R. (2006). Prolegomena to Library Classification. Ed. III. Reprint. Bangalore: Ess Ess Publications, Sandra Ranganathan Endowment for Library Science.

Saracevic, T. (1999). Information Science. Journal of the American Society for Information Science, 50(12), 1051-1063. https://doi.org/10.1002/(SICI)1097-4571

Saracevic, T. (2010). Information Science. In: M. J. Bates \& M.N. Maack (eds.). Encyclopedia of Library and Information Sciences (2570-2585). Boca Raton: CRC Press.

Satija, M.P., Madalli, D.P., Dutta, B. (2014). Modes of Growth of Subjects. Knowledge Organization, 41(3), 195-204. 
Szostak, R. (2013). The State of the Field: Interdisciplinary Research. Issues in Interdisciplinary Studies, (31), 44-65.

Wernli, D., Darbellay, F. (2016). Interdisciplinarity and the 21st Century Research-intensive University. Technical Report [online]. League of European Research Universities, [30.09.2020], https://doi. org/10.13140/RG.2.2.21578.16321

White, H., McCain, K. (1998). Visualizing a Discipline: An Author Co-citation Analysis of Information Science, 1972-1995. Journal of the American Society for Information Science, 49(4), 327-355. https://doi.org/10.1002/(SICI)1097+4571(19980401)49:4<327::AID-ASI4>3.0.CO;2+4

\title{
Interdyscyplinarność badań nauki o informacji: wprowadzenie
}

\begin{abstract}
Abstrakt
Cel/Teza: Artykuł ma na celu przedstawienie i omówienie wstępnych refleksji na temat istoty interdyscyplinarności badań prowadzonych w nauce o informacji oraz jej konsekwencji dla reorganizacji instytucjonalnego otoczenia dyscypliny.

Koncepcja/Metody badań: Jest to przeglądowy artykuł konceptualny, oparty na rozważaniach teoretycznych i krytycznych analizach pojęcia interdyscyplinarności oraz cech podejścia interdyscyplinarnego stosowanego w badaniach informacyjnych i jego konsekwencji dla ustalenia miejsca nauki o informacji w strukturze organizacyjnej uczelni.

Wyniki i wnioski: Pojęcie interdyscyplinarności omówiono w kontekście dwóch kluczowych zjawisk rozwoju nauki: specjalizacji i integracji. Przedstawiono wybrane typologie interdyscyplinarności oraz omówiono zmiany w postrzeganiu pojęcia dyscypliny. Omówiono interdyscyplinarność jako nieodłączną cechę nauki o informacji. Wskazano rodzaje interdyscyplinarności, które najlepiej odpowiadają specyfice podejścia interdyscyplinarnego stosowanego w badaniach informacyjnych. Nawiązując do wcześniejszych badań, wskazano na najbardziej charakterystyczne interdyscyplinarne powiązania informatyki. Generalnie oceniono, że poza trwałym związkiem z naukami społecznymi, w szczególności z bibliotekoznawstwem i informatyką, interdyscyplinarne związki nauki o informacji są zmienne i dość luźne. Silniejsze relacje generowane są najczęściej przez dziedziny działalności praktycznej i związane z nimi dyscypliny, w których wyspecjalizowane usługi informacyjne są najbardziej rozwinięte i szeroko stosowane, np. przez medycynę.

Oryginalność/Wartość poznawcza: Pogląd, że nauka o informacji ze swej natury jest interdyscyplinarnym obszarem badawczym jest powszechny wśród badaczy i specjalistów informacji. Przeprowadzono wiele badań dotyczących powiązań interdyscyplinarnych dyscypliny, jednak według najlepszej wiedzy autorki, w żadnym z nich nie analizowano specyfiki interdyscyplinarności tej dziedziny badań.
\end{abstract}

\section{Słowa kluczowe}

Interdyscyplinarność. Krosdyscyplinarność. Multidyscyplinarność. Nauka o informacji. Struktury instytucjonalne. Transdyscyplinarność. Typologia.

Professor BARBARA SOSINSKA-KALATA, PhD, is the Head of the Department of Information Studies at the Faculty of Journalism, Information and Book Studies of the University of Warsaw and the editor-in-chief of ZIN - Issues in Information Science, as well as a member of the Science of Science Committee at PAN (Polish Academy of Sciences). She specializes in information science, particularly in knowledge organization, and quantitative study of information, as well as history, theory, and methodology of information science. She published over 250 texts, including 12 monographs and 160 papers. Her recent publications include: Nauka o informacji wśród nauk o kulturze (Kultura książi i informacji, Katowice, 2017), Książka (dokument) 
w środowisku informacyjnym (Encyklopedia Ksiażki, Wroctaw 2017), The impact of the works by Paul Otlet and Suzanne Briet on the development of the epistemology of documentation and information science in Poland (Fondaments épistémologiques et théoriques de la science de l'information-documentation, London, 2018), Big data (dane masowe) w nauce o informacji (Zagadnienia Informacji Naukowej, 2018), Organizacja wiedzy w cyfrowym świecie: wpływ rewolucji cyfrowej na ewolucję metod i narzędzi organizacji wiedzy (Zagadnienia Informacji Naukowej, 2019).

Contact to the Author:

b.sosinska@uw.edu.pl

Department of Information Studies

Faculty of Journalism, Information and Book Studies

University of Warsaw

Nowy Świat 69

00-046 Warszawa, Poland 